\title{
The Spiritually-Based Organization: A Theoretical Review and its Potential Role in the Third Millennium
}

\author{
A Organização Baseada na Espiritualidade: Uma Revisão Teórica e seu Potencial Papel no \\ Terceiro Milênio
}

Anselmo Ferreira Vasconcelos ${ }^{1}$

\begin{abstract}
This paper examines whether the spiritually-based organization (SBO) can be regarded as an imperative for the third millennium. As a result, it draws on the literature review of organizational spirituality, psychology of religion, positive psychology, and spirituality leadership theory in order to support its conclusions, as well as it offers some research propositions. Overall, the evidence gathered throughout this paper suggests that the spiritual paradigm starts to play a key role alongside with the concept of SBOs. Rather, it concludes that these topics can be regarded as authentic imperatives for this millennium. Nonetheless, it argues that is likely to take some time until the spirituality topic may mold, so to speak, organizations' character regarding that spiritual theme is starting to become a noteworthy topic. Furthermore, it argues that the logic that has prevailed on business enterprises has been largely economic, except some honorable initiatives. The findings also indicate that the material paradigm is not suited to deal with germane problems that shape our today's world. Finally, it suggests that the concept of SBO embraces positive changes and, as such, it may be potentially conducive to improving people lives and the planet's health and equilibrium.
\end{abstract}

Keywords: Spirituality. Profit. Corporate social responsibility. Stakeholders. Religion. Leadership. Capitalist system.

\section{Resumo}

Esse artigo examina se a organização baseada na espiritualidade (OBE) pode ser considerada um imperativo para o terceiro milênio. Em consequência, recorre-se à revisão de literatura sobre espiritualidade organizacional, psicologia da religião, psicologia positiva, teoria da liderança espiritual a fim se dar suporte às conclusões, assim como se oferece algumas proposições de pesquisa. No geral, a evidência coligida ao longo desse artigo sugere que o paradigma espiritual começa a representar um papel-chave junto com as OBEs. Mais especificamente, conclui-se que esses tópicos podem ser considerados como autênticos imperativos nesse milênio. No entanto, argumenta-se que é provável que leve algum tempo até que o tópico da espiritualidade possa moldar, por assim dizer, o caráter das organizações considerando que o tema espiritual está começando a se tornar um importante tópico. Além disso, argumenta-se que a lógica que tem prevalecido nos empreendimentos empresariais tem sido largamente de natureza econômica, exceto algumas honoráveis iniciativas. Os achados também indicam que o paradigma material não é mais adequado para lidar com os relevantes problemas que modelam o mundo moderno. Finalmente, sugere-se que o conceito de OBE abarca mudanças positivas e, como tal, pode ser potencialmente condutor à melhoria da vida das pessoas e da saúde e equilíbrio do planeta.

Palavras-chave: Espiritualidade. Lucro. Responsabilidade social corporativa. Stakeholders. Religião. Liderança. Sistema capitalista.

\footnotetext{
The author is very grateful to Jürgen Menner and to the anonymous reviewers for their helpful comments and suggestions on an earlier version of this article.

Paper submitted on August $17^{\text {th }}, 2013$ and accepted for publication on August $18^{\text {th }}, 2014$.

DOI: http://dx.doi.org/10.1590/1679-395110386

${ }^{1}$ MS in Management from Pontifical Catholic University of São Paulo; Independent researcher. Address: Rua Fradique Coutinho 587, apto. 31 D, CEP 05416-010, São Paulo - SP, Brazil. E-mail: afv@uol.com.br
} 


\section{Introduction}

Although we are living in an era of great scientific advances, huge technological breakthroughs, conflicting societal demands and uncertainties there is no compelling evidence that organizations are getting to be aligned with deeper changes. In fact, it seems that the majority of firms are still imbued by an unwise ethos whereby their workforces feel depleted and unhappy. In this sense, Frost (2003) identified great pain and suffering, inside and around organizations. As a result, he regarded the organizational life as a no benign experience. Similarly, Leavitt (2007) refers to the companies as being flawed, erosive, imprisoning, and unhealthy entities. Overall, this scenario can be the upshot of a range of undesirable things and events, especially the frenetic global competition, which has caused sizeable emotional discomfort and stress. Furthermore, the workaholism corporate culture - another disturbing effect of this trend - is widespread worldwide. As a result, workers are compelled to spend increasing time at their jobs - like it or not. To a large degree, the contemporary experience of corporate life somewhat hinders the search for a work life balance (e.g., LIMA, CARVALHO NETO, and TANURE, 2012; VASCONCELOS, 2008). Worse still, people are no rare treated as mere disposable goods regarding that any unpredicted shift in business arena, firms quickly get rid of them.

In its most basic sense, the logic that has prevailed on business enterprises has been essentially economic, except some honorable initiatives (see, e.g., VASCONCELOS, 2008; 2011b, for a review). Accordingly, mission statements, business strategies, structures, and organizational discourses are usually disposed toward growing profits, market expansions, and return on investments. Rather than searching for cooperative efforts toward building healthy and sustainable societies, corporate life seems like a war (WADDOCK, 2005). Furthermore, several pillars of modern capitalism such as transparency, customer satisfaction, fair profit, and respect for law, to name a few, are shaken up due to executives' misconduct and misbehavior. Therefore, it is not an exaggeration to say that the organizational environments shaped by these sorts of corporate goals tend to be nurtured by the greed and voracity of their decision-makers - probably dispirited ones. As a consequence, their corporate actions will likely echo organizational deviances (VASCONCELOS, 2011a). In a related vein, Boddy (2011) proposes that the current global financial crisis was triggered by what he labeled as the corporate psychopaths. Although such a landscape is not exactly new (KETOLA, 2006), the issues raised by that are still waiting for suitable responses.

In contrast, there are organizations interested in providing not only economic value to society. This must be regarded as a very positive signal, given that this post-modern era is calling for more responsible and conscious companies (VASCONCELOS, 2011a). Indeed, it is expected that these organizations be able to address their traditional business concerns and societal ones in a wiser fashion. In other words, it is expected that they also deal with stakeholder' needs in a respectful and sensitive way (GIOIA, 2003). Moreover, as employers, they should meet their employees' wants, needs, aspirations, and dreams in such a way that gifted people feel compelled to work for them, as well as to advocate their missions. Finally, they should be highly proficient in terms of triggering the best perceptions toward their corporate brands. On the face of it, one research question is proposed: can the concept of spiritually-based organization (SBO) encompass the positive features above outlined?

Therefore, the purpose of this paper is to examine whether the SBO is an imperative for the third millennium. Bearing it in mind, it first explores some theoretical antecedents (i.e., the dark side of organizations and other signals of disruption) and discusses some key aspects that appear to be leading to the emergence of a spiritual paradigm (i.e., the need of humanizing capitalism). Second, the paper examines the scope and meaning of spiritual paradigm and its impact on organizations. Third, it reviews the features and concerns, potential benefits, and challenges associated with SBOs, as well as it offers some research propositions. Next, it suggests the relevance of the leadership factor within this overall framework. Subsequently, it examines some counterpoints, difficulties, and problems. Finally, it discusses some possibilities of future studies and the conclusions are presented. 


\section{The Dark Side}

Many aspects have contributed to shape the image of organizational environment as a negative one (which somewhat has lead us to start this discussion). In this section, I intend to deepen the analysis of some critical issues and examine other ones. Thus, the first issue focuses on the capitalist system given that it leverages the majority of people lives. So far, it is seemingly the most efficient economic arrangement that humankind has ever invented, despite its ongoing shortcomings and financial downturns. Further, it is the capitalist system that challenges entrepreneurs, executives, workers, and organizations to perform better every single day just as they were perfect machines. To a large degree, this logic is absolutely perverse, particularly when the outcomes are below the line regardless of the functional disruptions, collective failures, environmental threats, and management misperceptions, inter alia. ${ }^{2}$ Moreover, "When capitalism marches roughshod over cultural values, religious beliefs and ethnic traditions, it is reducing every living person in its path to a 'thing'. This is dehumanizing" (RENESCH, 2008, p. 5). It is also noticeable that many professionals become obsolete overnight due to the technological breakthroughs. In addition, today's work life usually puts great pressure on people and the career laddering becomes the center of their existences. Consequently, more time and energy have been devoted to work in detriment of other important aspects of life (CAVANAGH, HANSON, HANSON et al., 2004).

Although businesses are economic institutions, they are not only economic ones. In fact, one may produce undesirable side effects when one supports only this paradigm (CROPANZANO, BOWEN and GILLILAND, 2007). Nonetheless, one can see this sort of business enterprises and its outputs in the current landscape without any difficult and, as such, it is problematic in varying degrees. For example, some authors pose that "The temptation for individuals is to measure their worth in terms of their income and possessions. The market system today also places pressure on individuals and groups to make business decisions solely on the basis of profit. Material possessions thereby become the highest value" (CAVANAGH, HANSON, HANSON et al., 2004, p. 121).

In a related vein, Balch and Armstrong (2010) recognize that the high performance organizations (e.g., Enron and Microsoft) are strongly dedicated to pushing boundaries, reaching new levels of performance and efficiency, challenging dogma, doing things differently - breaking old rules, and making new ones. They also create a performance culture that drives and encourages individuals to think outside the box, question assumptions, dare to innovate, and celebrate the value of taking risk to achieve goals. Nonetheless, "The problem arises when productive iconoclasm is overextended... When this happens, organizations may use legitimizing myth to explain why their ethically questionable behavior is really acceptable" (BALCH and ARMSTRONG, 2010, p. 296). Such a concerning is appropriate regardless of business ethics has been gaining room through the last decades and its importance for corporations (MEIRA, 2010). Nonetheless, Freitas (1999) argue that organizations feel comfortable by assuming a role of somewhat defenders of the countries from economic crisis which ordinarily affect rich and poor nations, as well as (supposedly) by adapting the domestic economies to the requirements of globalization process. In fact, the neo-liberalism discourse sells companies as being key-players able to be rid of crises and role models to other social institutions and, as such, they are being accepted by society. But such a discourse usually does not take into account the effects emanated from rising prices, product standards manipulation, cheating strategies, and reduced workforce, among other detrimental measures enacted by organizations in order to keep or even enhance their profitability, especially in countries like Brazil where not only economic driven organizations seem to be a wishful thinking. Taken together, one may surmise that the darker side of the capitalist system will continue to represent a real nightmare in the life of many people unless the prevalent mindset changes.

2 For example, Felix, Salgado and Balieiro (2013) reported today's harsh situation that has been faced by CEOs of Brazilian large organizations. According to them, the cycle of CEO in a job has been reduced, on average, from $3 / 5$ to 1.5 years. In a nutshell, CEOs have not had enough time to deliver outstanding outcomes to shareholders. 


\section{Other signals of disruption}

On the other hand, researchers have identified a kind of organizational anomaly - as a by-product of this general frame - that has been labeled as organizational terrorism. Caldwell and Canuto-Carranco (2010) define it "as the actions of any organization member which are taken to further a self-serving personal agenda that undermines the long-term welfare and growth of the organization and denies the rights of organization members" (p. 160). These authors also argue that the obligations of leadership and responsibilities of governance cannot accept management style values supported by those who behave like organizational terrorists and seek to impose their own will on organizations.

It is also worth reminding that the statistics about the number of workers worldwide who are searching for jobs currently (e.g., Spain and Greece to name a few). Even for those workers that have one, the landscape seems to be unpleasant. Indeed, evidence shows that employees are suffering from burnouts, depression, anxiety, and mental health problems (HAYAKAWA, 2009). On the whole, this is a very disturbing fact, particularly when one considers that work satisfaction remains as a genuine human beings aspiration. In a related vein, a study found evidence that "organizations are a primary mechanism for generating inequality in society" (DAVIS and COBB, 2010, p. 38, italics in the original). Not surprisingly, this investigation also revealed that the essence of inequality stands on corporate hierarchies. Further, McKnight (2005) remarks that a business model where organizations are portrayed as cold or impersonal machines thwart the notion of humanness. McKnight also recognizes that we have needs in three areas, namely: body, mind, and spirit. Therefore, whether people are the masterpiece of God's creation in this planet, it does not make sense to scoff their needs. Taken together, this scenario has enabled the proliferation of sick organizations, dispirited leaderships, as well as poor business goals. Regrettably, one may not envision substantial shift at least in the near future.

\section{The need of humanizing capitalism}

All things being equal, I believe that one will have to humanize the prevailing economic system in order to bring some light and balance on it. ${ }^{3}$ In this regard, Renesch $(2008$, p. $7-8)$ suggests that we can start by making more mature decisions and wiser choices both individually and collectively. More specifically, as workers, consumers, family members, and citizens of the world, it is paramount that we stop living as whether there will be no tomorrow. He contends that we have behaved like adolescents who are not fully matured emotionally. To him, people must be responsible for anyone's life and for their impact in the worldthat is, people around us, nature, as well as people who we do not necessarily know. Renesch proposes many initiatives such as starting honoring our differences both domestically and globally; engaging in dialogue to see what we all want, jointly and separately; stopping disrespecting "less civilized" cultures because we supposedly think we know better, or we think we have the technology to "improve" things from our perspective; diminishing our arrogance, our know-it-all attitude and engage with the world, with nature and each other with a bit more humility; beginning speaking out publicly, that is, to stand up and be counted when we think things are not going the way we think they should; and stopping remaining silent when our inner voices are telling us that something is not quite right because it is like denying our spirit.

${ }^{3}$ One path to mitigate such a scenario is through the incorporation of broader corporate citizenship and corporate social responsibilities, which are regarded as pillars that help build spiritually-based organizations (VASCONCELOS, 2008). In this sense, as put by Glavas and Piderit (2009), "[...] Corporate citizenship does not imply whether it is morally good or bad to have an impact on stakeholders and the natural environment. It implies that it is good business to treat your stakeholders and the environment well" (p. 53). In the same vein, Waddock and Mclntosh (2009) note that "[...] Simple corporate 'social' responsibility measures, where companies attempt to "give back" to the community or stakeholders, will be insufficient to accomplish this shift. What is needed is systemic change that returns corporations to their original roots of serving social, not purely economic, interests, a sensibility oriented toward conservation and thrift rather than profligacy, and leaders with quite different mindsets than are currently being fostered in most management education and development programs" (p. 304). 
According to Renesch (2008), "Humanizing capitalism means to make it "people friendly"” (p. 8). In effect, Gavin and Mason (2004) claim that the search for improvement in productivity alone, which constitutes almost the sole concern of many organizations is not enough. In light of this, López, Ramos, and Ramos (2009) and Pfeffer (2003) criticize businesses that focus only on the goal of maximizing shareholders' value and profits at the cost of their mission and values because they can discourage employees from revealing their spirituality in the workplace. Not surprisingly, dispirited workplaces have been associated with low morale, high turnover, burnout, frequent stress-related illness, and rising absenteeism (THOMPSON, 2000). On the face of it, I propose that organizations will likely have to face some dilemmas in some moment of their journeys whether they intend to echo a brighter face.

As Figure 1 tries to show, it essentially depicts two opposite views, yet some variations may be identified. More specifically, I propose that organizations have basically two distinct paths to pursue in this new millennium, that is, either they can be a source of pain or they can be a source of progress. The former possibility predicts that people might continue to feel fear, frustration, discrimination, resentment, uncared, unhappiness, and disloyalty as a causal effect of firms that stay focusing on just material values and see profit as a means to promote the well-being of a few people, particularly shareholders.

By contrast, the latter alternative posits that people feel trust, loyalty, success, pleasure, happiness, and care for. Further, it is also expected that diversity practices be welcome and their beneficial results may be noted throughout the organization. Viewed in this way, organizations would focus on both material values and nonmaterial ones and profit would represent a path to lead to the general well-being. Again, Figure 1 does not cover all potential variables and nuances; however, the most important is the dilemmas that it tries to evoke.

Figure 1

\section{Some of organizations' dilemmas in the third millennium}

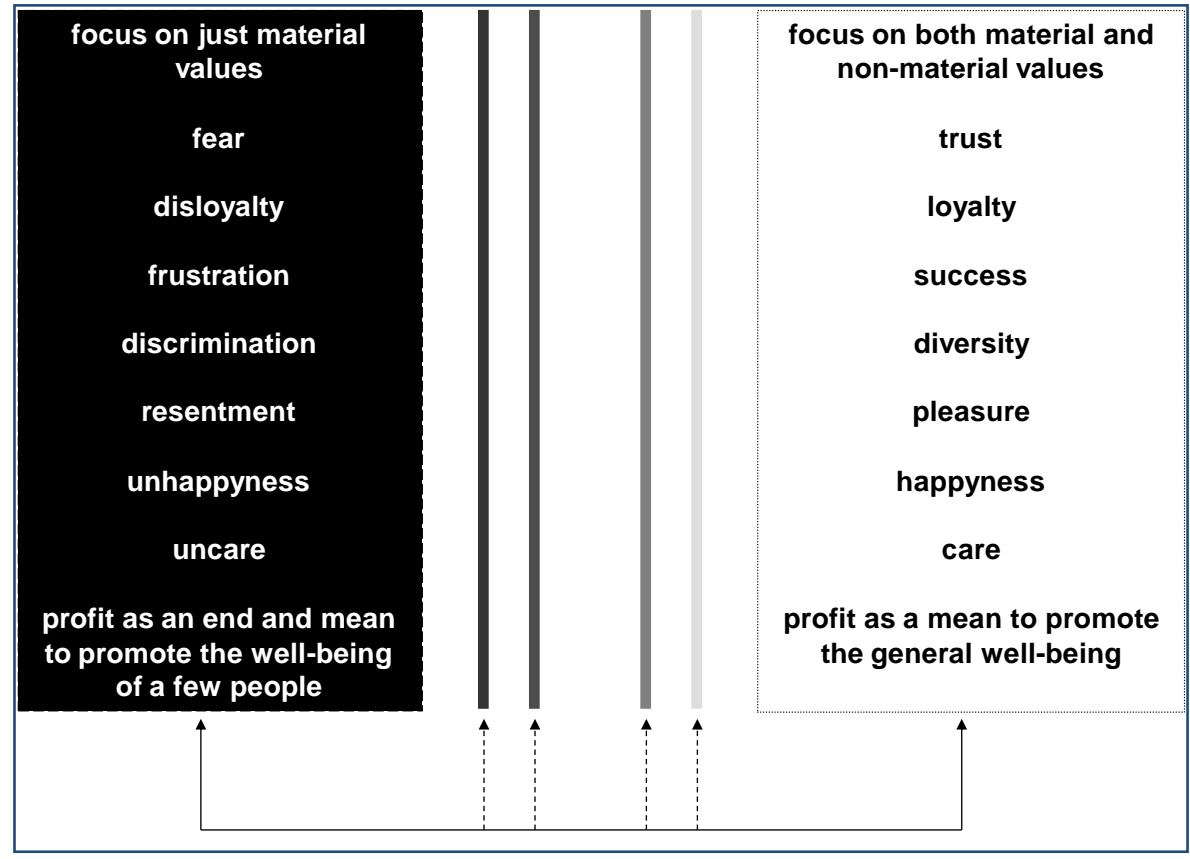

Source: Author

Moreover, it is predicted that through the left side of Figure 1 would remain some harmful effects such as the depletion of planet natural resources, environmental degradation, growing impoverishment, increasing unemployment rates, ongoing financial crises, and the likelihood of a large number of unexpected climate events. Meanwhile, the right side suggests a more rational and self-sustainable path given that crucial aspects likely would be on the centerpiece of organizational decisions such as preserving the planet, keeping 
people's health and well-being. Put differently, the left side maintains the current business-model whereby organizations have given almost entire primacy to material paradigm, whereas the right side requires other business model.

\section{Spiritual Paradigm}

Nonetheless, there are clear cues indicating that one has never talked and published about spirituality more than one does now. Further, some authors advocate that it has already reached such a level that we are living an authentic spirituality revolution (e.g., TACEY, 2004). In fact, there has been published a plenty of books (including self-help literature covering at least some aspects of this subject), papers, and even scientific journals, do not mention well-known annual conferences dedicated to this topic. Taken as a whole, this growing interest suggests that people are willing to develop their spirits by facing their shadows, discovering new capabilities, behaving more ethically, and being better human beings, among other things. Overall, the resurgence of spirituality theme embraces myriad of aspects and issues.

On the whole, it appears that the spirituality theme is now more than a fashion. Actually, it has been argued that this change encompasses: the holistic/ecological/systemic view of reality; the world regarded as a complex, interconnected, infinite, ecological, social-psychological-economic system; the understanding that different laws apply at different levels of reality; the notion that the world is to be enjoyed; the emphasis on energy and flow; the need of both intuition and reason; the change conceived as having multiple causes, as being subtle and unpredictable; the notion that each situation or event is unique and its outcome is not controllable simply by applying general laws; the understanding that confidence, expectation, and love are critical aspects of causality; the belief that all knowledge should be seen as "interested knowledge"; the perspective of people be treated as multi-dimensional beings with a life outside the organization; the understanding that fulfillment should be sought through the opportunity to pursue lofty (even cosmic) objectives in line with people's deepest spiritual values; the belief that alignment should be achieved through commitment to a common vision; the leader's role in terms of inspiring and teaching; the understanding that problems should be solved participatively with staff at all levels making their contribution; and the management role regarded as a performing art (see HOWARD and WELBOURN, 2004, p. 32).

In addition, it is suggested that this new paradigm embraces more than a set of propositions, insights or perceptions because "the different views of reality represented by spirituality and science can come together to form a single, holistic worldview" (HOWARD and WELBOURN, 2004, p. 33). Furthermore, this view holds that religion and spirituality are not at odds and, accordingly, it is likely that religious traditions and tenets can incorporate spiritual knowledge without the stimulus of a blind faith or inconsistent arguments. As such, religion might be suffused by the concept of a new paradigm. Under this perspective, religion might be open to accept an emphasis on mysticism and intuition; belief in a divinity/ultimate reality which has both male/transcendent and female/immanent aspects; show willingness to draw insights from other faith traditions; accept and learn from science and all other sources of human wisdom and knowledge; accept, while remaining creatively critical of, the modern world; and be deeply concerned for, and engaged with, planet Earth and keen to work alongside all others dedicated to co-creating its future (HOWARD and WELBOURN, 2004, p. 103). Despite the topic of spirituality is regarded as a taboo in many organizations (see EXLINE and BRIGHT, 2011), this paradigm has taken to the need of reviewing certain beliefs, values, perceptions, and views about how we live in this world.

On the other hand, spiritual paradigm depicts some theoretical overlaps and convergences with Positive Psychology (PP), Positive Organizational Scholarship (POS), and Positive Organizational Behavior (POB). Rather, it must be pointed out that spirituality is one of the core components of positive psychology. In this regard, it is noteworthy to point out that PP looks for catalyzing a change in the focus of psychology from preoccupation only with repairing the worst things in life to also building positive qualities (SELIGMAN and CSIKSZENTMIHALYI, 2000). In essence, PP focuses on human-beings' virtues, strengths, and goodness or, in other words, domains or features derived from spiritual nature which rests inside us. 
According to Cameron, Dutton and Quinn (2003), POS, in turn, is concerned with organizational dynamics that encompass words and outcomes associated with excellence, thriving, flourishing, abundance, resilience or virtuousness. Importantly, POB is seen as the states that easy to be open to learning, development, change, and management in the workplace (LUTHANS, 2002). In sum, "Whereas POB tends to focus more on micro-level issues related to employee development and performance, POS is aimed more at macro organizational issues, although there is recognized overlap between the two approaches" (LUTHANS, AVOLIO, AVEY et al., 2007, p. 10). Overall, it suggests that spiritual paradigm, including its theoretical contribution toward the workplaces, embraces the theoretical developments in those fields given that the spiritual issue is one of the most vital aspects - perhaps the greatest - of the human essence.

\section{Some words about the phenomenon of spirituality}

Researchers believe that spirituality is in its infancy in terms of conceptual development (e.g., EMMONS, 1999). According to Pargament and Mahoney (2005), since the 20th century psychologists have somewhat neglected spirituality. Rather, they have regarded it as pathological or treated spirituality as a process largely dependent of psychological and social spheres. Nonetheless, the reappearance of this topic, especially in the last decade, denotes that something very important was being sidelined (see, e.g., KHISTY, 2010). In fact, spiritual knowledge can enable us to face the twists and turns of life by means a psychologically healthy state. Oftentimes spiritual experiences seem to increase one's life's challenges (NOBLE, 2001). Following this line of reasoning and drawing on Kardec's (1857/2003) studies, Vasconcelos (2010) argues that people should search for incorporating virtues on their personalities, acts, and thoughts as an ongoing exercise in order to prevent them from suffering in the future (including future lives).

In fact, the corporate life might be substantially enhanced when people take into account the need of those improvements in their daily tasks. Moreover, this view suggests that envy, callousness, selfishness, betrayal, mercilessness, insensitivity, gossip, disservice, and negligence emanate from people's moral weaknesses. Thus, spiritual paradigm reminds us that "our spiritual duty is to use our free will to help and not harm others to further their ends" (LIPS-WIERSMA and NIKALANT, 2008, p. 59, emphasis added). In effect, this assumption is somewhat embedded on Jesus Christ's teachings, more specifically the one which advises us to "Be ye therefore perfect, even as your Father which is in heaven is perfect" (see MATTHEW, p. 5: 48, emphasis added).

Importantly, spirituality is seen as a multi-faceted, multi-dimensional, and multi-level phenomenon or construct (GOTSIS and KORTEZI, 2008; NECK and MILLIMAN, 1994; PANDEY and GUPTA, 2008; TWIGG and PARAYITAM, 2006), which embraces a myriad of meanings and understandings. For example, Elkins and colleagues (cited in CHAMIEC-CASE, 2006, p. 9-10) developed a painstaking and detailed conceptualization of spirituality that embraces nine major components, namely: (a) transcendent dimension; (b) meaning and purpose in life; (c) mission in life; (d) sacredness of life; (e) material values); (f) altruism; (g) idealism; (h) awareness of the tragic; and (i) fruits of spirituality. In more succinct terms, Shore (cited in Emmons, 1999, p. 109) suggests that spirituality is the process of replacing the self as the source of ultimate concern with family, community, humanity, and divinity (see also LIPS-WIERSMA and NIKALANT, 2008). To some degree, such a personal shift reinforces Emmons' (1999) opinion whereby he regards spirituality as a personal transformation.

Meanwhile, some authors put spirituality in a more transcendent level. For example, Stoltz-Loike (1997) suggests that "Spirituality is the cognition that we can be influenced by factors that extend beyond the tangible concerns that we have in our daily existence. It reflects the human yearning to touch something greater than ourselves" (p. 152, italics in the original). In a related vein, Pargament and Mahoney (2005) posit that the sense of spirituality can be experienced through the feeling of the transcendent in the everyday occurrences of life. 
Taken together, one can infer that spirituality is strongly related to our earthly experiences and daily situations. Seen in this way, spirituality enables people to make very important things such as breathing new life into endeavors, recreating individuals and group, restoring hope (KORAC-KAKABDASE, KOUZMIN and KAKADBASE, 2002), being self-managed, adult, self-direct, and promoting their conscious development (DENT, HIGGINS and WHARFF, 2005), helping them to see that their ultimate purpose is that work be done with the intention of a higher or greater good (ASHAR and LANE-MAHER, 2004; KINJERSKI and SKRYPNEK, 2004). Therefore, "it is not surprising that many artists and scientists have become interested by spirituality" (LOZANO and RIBEIRA, 2004, p. 178).

The potential impact of this paradigm on organizations

Obviously, these changes have spilled over organizations to the point that researchers have suggested that there is growing evidence that an organizational fourth wave has taken place through the concept of SBOs (e.g., WAGNER-MARSH and CONLEY, 1999). In fact, nowadays organizations have been compelled to align their corporate values with their employees and work hard to solve society conundrums as well. Put another way, organizations are starting to understand that they do not exist in a vacuum or different stance. Further, there is no doubt that they play an important role in this world and everything they do impact somewhat our lives. Under the lens of spiritual paradigm, they are seen as performing more accountable, conscious, and equitable roles. Exploring this logic, Vasconcelos (2010) regards that the spiritual paradigm has gradually become from an apparent fad management to a respectful theme. He notes that it is increasingly attracting intellectual curiosity and personal search for understanding this phenomenon. Furthermore, researchers from different religious and non-religious streams have currently identified and explored a myriad of constructs and dimensions related to spirituality on corporate life. Similarly, managers and workers have found in it a mechanism of reawakening of something more powerful that is innate in them.

In addition, Vasconcelos (2010) suggests that this mechanism may help them to utterly express their inner strengths. Organizations, in turn, have concluded that nurturing spirituality in the workplace is very beneficial in many aspects. Indeed, spirituality and religion are subjects usually closely intertwined on human beings' odysseys. In this light, the study of these topics on organizational environments is pertinent, especially when one takes into account that organizations are entities that do not exist by themselves. In fact, organizations are a wholeheartedly human creation and, as such, they have undergone ongoing interventions to meet human needs. Nonetheless, since the 1980s organizations have reflected a not so brighter face regarding the plethora of downsizings, layoffs, and financial crisis that have taken people to look for more lasting things like the spiritual principles. Thus, the spiritual paradigm may apparently help transform the nature of the management task by means of a deeper understanding.

However, it is not feasible to enhance our spirituality whether we do not look at the dark side of life actually, this can be regarded as a starting point - which affects the individual, the organization and the systemic paradigm and their "realities of imperfection, failure, and sin" and related aspects such as "greed, exploitation, environmental degradation, insensitiveness, lack of empathy, abuses of power, and failures of stewardship", as proposed by McGee and Delbecq (2003, p. 96). Therefore, in order to reduce the consequences of such imperfections is vital "the realization of the nobility possible in the work of business, especially the work or organizational leadership..." (MCGEE and DELBECQ, 2003, p. 96). Lastly, it is suggested that organizational spirituality can transform radically "the dysfunctional precepts and actualities of modern, bureaucratic organizations" (STEINGARD, 2005, p. 235). In contrast, Grzeda and Assogbavi (2011) understand that a more compelling argument is needed in order to associate unique outcomes with organizational spirituality. Either way, they alternatively propose a healing framework in which spirituality in the workplace would advance until the achievement of a transformed mission toward healing and repairing. 


\section{Spiritually-Based Organization}

Thus far, there is no a clear definition of what really means a SBO. Although the field is seemingly in a more paradigmatic developmental stage, it still requires a consensus in relation to ontology, definition and conceptual frontiers (BADRINARAYANAN and MADHAVARAM, 2008). Surprisingly, there has been scant investigation focused on the organizational level (e.g., ALTAF and AWAN, 2011; DELBECQ, 2009; DHIMAN and MARQUES, 2011; MARQUES, 2007; MILLIMAN, FERGUSON, TRICKETT et al., 1999; MITROFF and DENTON, 1999; OUIMET, 2002; PAVLOVICH and CORNER, 2009; QUATRO, 2002; VASCONCELOS, 2008; 2011b; 2013; ZAIDMAN and GOLDSTEIN-GIDONI, 2011).

Regardless of the difficulties, Guillory (2001) proposes that spirituality in the workplace involves the integration of humanistic principles, practices, and behaviors with sound business functioning. Therefore, a SBO could enable an employee-friendly work environment, service orientation, creativity and innovation, personal and collective transformation, environmental sensitivity, and high performance. Pandey and Gupta (2008) argue that a SBO adopts a caring attitude towards existence, as well as it is engaged in meaningful work in whatever area it is operating. Thus, its managerial decisions are inspired by the awareness in social, natural environment, and the larger society. In addition,

Spiritual consciousness emphasizes on equilibrium with market requirements, social needs and natural environment. In these organizations human beings are viewed as multipotential, meaning seeking entities. Organizations moving from market consciousness to social and spiritual consciousness achieve better integration of ideals of efficiency, equity and equilibrium. (PANDEY and GUPTA, 2008, p. 896).

Therefore, as proposed by Vasconcelos (2011b), at the simplest level, the concept of SBO should embrace at least some salient features, namely: (1) it should meet the needs and demands of society through ongoing corporate social responsibility actions (e.g., by adopting the practices of doing good, promote the well-being of stakeholders, behaving ethically, going beyond its own interests, satisfying societal wants, and building strong reputation); (2) it should also show consistent internal marketing policies in order to value its employees (e.g., by fulfilling internal customers' needs, providing strong human resources policies, promoting work motivation and job satisfaction, enabling happiness in the workplace and getting employee's trust, involvement, engagement, and commitment with organizational goals). As a result, a SBO would tend to achieve suitable outcomes in its business operation and be admired by society as a whole. On the face of it, one can deduce that SBO enlarges its social role by recognizing moral principles as a compass and simultaneously working ethically to meet societal needs.

Within this perspective, it seems that SBO strives for a mission statement that embraces only noble obligations, that is, to be held accountable for worthy initiatives. In this sense, Marcic (2000) ponders that SBO adopts this path because it is just the right thing to do. In my view, this reasoning is absolutely perfect. After all, mankind needs companies that contribute to their health and well-being, as well as to be committed to preserving the planet. Taken as a whole, therefore, a SBO is seen as a kind of organization that shows strong commitment to sharing wealth, disseminating knowledge, enhancing the well-being of its customers, engendering progress, and collective well-being (VASCONCELOS, 2011b). Based on the arguments aforementioned, I offer the research proposition as follows:

Proposition 1: regarding its characteristics, concerns, and outcomes a SBO likely will be more capable of being recognized and awarded by society.

\section{What are their features and concerns?}

Regarding that spirituality is posited as a very important component of all management systems (MITROFF, 1998), one may surmise that almost any institution is potentially capable of encapsulate the spiritual 
paradigm, except criminal and terrorist organizations, as well as corrupt governments. Further, researchers conceptualize that the SBO should exhibit flatter structures and a considerable openness to change. More importantly, it is believed that the SBO might engender greater interconnectedness and co-operation between organization units and empowerment of workers at all levels of the organization (BIBERMAN, 2009; BIBERMAN and WHITTY, 1997). In a related vein, Lawler (2003) argues that organizations that search for spiritual or noble purposes are generally successful in terms of establishing goals toward motivating and retaining their employees.

It is noteworthy to highlight that a SBO pits against the idea of producing "dangerous or shoddy products, abused employees, disowned the bad consequences of one's products and services for the larger society, and so forth" (MITROFF, 2003, p. 191). Rather, SBOs may monitor themselves by formulating and answering harsh questions in a continuous fashion (see, e.g., MARQUES, DHIMAN and KING, 2007, p. 157-158, for some pertinent suggestions). The spiritual workplace is usually portrayed as capable of providing an employee-friendly work environment in which one finds acknowledgement, support and development to the spirit of its employees (e.g., BADRINARAYANAN and MADHAVARAM, 2008). On the other hand, Benefiel (2005) claims that SBOs tend to perform better and, as a consequence, enrich their stakeholders. Nonetheless, she emphasizes that such an outcome is derived from sustainable profit, the reputation for quality and integrity in their products and services, reduced employee turnover, the ability of building longterm trusting relationships with customers and suppliers, as well as by giving back to the communities in which SBOs are located. Further, according to Zohar and Marshall (2004), companies fueled by the spiritual paradigm establish their goals and strategies taking into account a wider context of meaning and value. As a result, one may also elicit the following propositions:

Proposition 2: regarding its characteristics, concerns and outcomes a SBO likely will be recognized by the quality of its products and services.

Proposition 3: the workforce of an organization that fits into a SBO frame likely will exhibit low level of absenteeism, turnover, job dissatisfaction, and unhappiness in the workplace.

Exploring other aspects, Vasconcelos (2011b) argues that well-known spiritualized characters like Jesus Christ, Mahatma Gandhi, and Moses, among others, are thus recognized for the sake of their ideas, feats, behaviors, and acts. Similarly, he proposes that the concept of SBOs takes into account the same things (variables). Thus, one could certainly identify their organizational identity (i.e., who they really are) by investigating their achievements, organizational policies, strategies, held values, and official statements through an ongoing basis. This author also proposes that the most effective way to find whether an organization follows an organizational spirituality orientation is by probing, for example, what it does to keep itself alive, how it behaves and how it is seen by society. Through the analysis of these aspects one could (1) obtain appropriate answers to sensitive questions, (2) elicit the real organization purposes (3) and find its level of spiritual orientation, if any.

Similarly, Karakas (2010) calls attention to the fact that some corporations like Body Shop and Tom's Maine incorporate the spiritual paradigm into their strategies of corporate social responsibility. Thus far, one may infer that the concept of SBO is theoretically richer (i.e., it appears to be a first-order construct) given that it encompasses many other constructs. In this sense, some studies examined, for instance, the overlaps or theoretical linkages between the societal marketing concept and spirituality in the workplace theory. Rather, Vasconcelos, (2011a) found evidence of theoretical overlapping in some constructs, namely: employees, work, workplace, quality of life, ethics, corporate citizenship, and social responsibility. Finally, it has been suggested that a SBO is built on some pillars such as vision, values, God, moral, ethics, social responsibility, and organizational citizenship (VASCONCELOS, 2008). Apparently, the concept of SBOs shows important characteristics that could transform companies into wiser and helpful entities. On the face of it, I suggest that

Proposition 4: a SBO likely will broaden the scope of their corporate social responsibility policies in order to be more beneficial and fair toward customers, stakeholders, employees, and society as a whole. 


\section{What one can expect from them (potential contributions)}

Thus far, the arguments that have been presented describe that the concept of SBO embraces positive changes. As such, this kind of organization may be potentially conducive to improving people lives and the planet's health and equilibrium. In this sense, evidence shows that our planet is sick and organizations have substantially contributed to it. Nonetheless, "Companies that build spirit treat with dignity and respect, as people, not simply as economic agents or as factors of production" (PFEFFER, 2003, p. 41). In effect, if they had already provided these benefits, arguably we could have reached a considerable advancement within our organizations and work dimension. Either way, the extant literature allows us to conjecture that through SBOs employees could be nurtured with professional development, meaningful careers, quality of working life, respect, valuing, diversity and inclusion orientation, and so forth. After all, empirical evidence indicates that the benefits of labor-friendly organizational practices outweigh the costs in such a way that it leads to the conclusion that what is regarded good for employees turns to be also good for shareholders (e.g., FALEYE and TRAHAN, 2011). Therefore, from the above discussion one may also elicit the following propositions:

Proposition 5: regarding its characteristics, concerns, and outcomes a SBO likely will be committed to implementing outstanding organizational policies toward valuing and respecting all groups of its workforce.

Proposition 6: regarding its characteristics, concerns, and outcomes a SBO likely will be strongly engaged in putting into practice both inclusive policies and affirmative actions.

Drawing on POS theory, which it is supposed to have strong linkages with organizational spirituality theory (LAVINE, BRIGHT, POWLEY et al., 2014; VASCONCELOS, 2008), it is worth reminding Park and Peterson' (2003) remarks about what a good organization - and it is also assumed here that this one of the features of SBOs - might trigger on people. Rather, they surmise that it "can inspire its members to be more than they are - to reveal strengths of character that are dormant or to create new ones that allow them to rise to the occasions deemed important by the organization" (PARK and PETERSON, 2003, p. 46-47). Interestingly, research has showed that employees who work for this sort of organization are less fearful, more ethical and more committed (FRY, 2005, p. 57). For this reason, I suggest that:

Proposition 7: regarding its characteristics, concerns, and outcomes a SBO likely will be strongly committed to ethical conduct and moral tenets.

Similarly, Johnson (2009, p. 77) notes that SBOs nurture the entire person, that is, his or her emotions, selfworth, aspirations, and desire for purpose - while cultivating a sense of membership. In addition, when situation requires layoffs, they are handled with empathy and care (EVERS and REID, 2009). Importantly, it is advocated that

In an organization high on spirituality awareness, values and mission statements are not forgotten documents but are engaged through a continuing process of reflection. The ongoing engagement with missions and values, supported by the organization's spiritual efforts, can impel organizations to re-conceptualize their orientation to their mission (GEH and TAN, 2009, p. 296)

\section{Some challenges}

At this juncture, one can surmise that the spiritual paradigm impels organizations as well. In fact, evidence shows that several companies worldwide have done praiseworthy things and, in doing so, they appear to be encompassing a spiritual frame (e.g., VASCONCELOS, 2008; 2011b). Nevertheless, it must be recognized that it sounds to be a huge and very complex challenge to transform a traditional organizational into a spiritual one. After all, it implies to change the current mindset, held-values and its leaderships way of seeing 
the whole picture. As Gull and Doh (2004) rightly posit, the organization "must fundamentally change its view of itself and its place in the world" (p. 136). To follow through that aim, therefore, organizational leadership should be engaged to this task. In addition, many efforts likely would be needed to be put into practice in a daily basis. However, Pava (2003) noted that there is no specific formula to integrate business and spirituality, yet all human activities mirror some level of spirituality. Further, he believes that, in a more basic level, the major effort to make organization more spiritual is to make organization more humane. In a related vein, Stead and Stead (2014) call attention to the sensitive issue of sustainability, that is, a multifaceted concept with deep spiritual roots. These authors argue that to build triple bottom line strategies organizations need to develop spiritual capabilities (i.e., spiritual intelligence and spiritual capital).

Overall, as highlighted by Ashforth and Pratt (2003), there is no doubt that the idea of spirituality alone is not enough to sustain an organization. In this sense, the conundrums and problems derived from the omnipresence, influence, and power of organizations likely will not be fixed overnight. Very often organizations play a blurred role and yield mixed outputs, even when they allegedly exhibit societal concerns. It is clear that firms have developed themselves since industrial revolution time. But there is no denying that since the mid 1980s and early 1990s a sizeable number of mergers, acquisitions, and lean structures programs have taken place everywhere causing unfavorable perceptions and opinions about organizations. Stated differently, it appears that organizations have been problematic in many areas and dimensions, despite some advancement (see, e.g., SUTCLIFFE and CHRISTIANSON, 2012). Nonetheless, from a spiritually-based standpoint, corporations should strive to show that they are worthy organizations and are inspired by a higher sense of purpose, as suggested, for instance, by Garcia-Zamor (2003). Further, it is posited that they should be committed to reaching and providing three purposes or goals, namely, service to society, economic health, and ethical values (BAKKE, 2005). To some extent, I believe that an organization may show that it is prone to the assimilation of the spiritual paradigm discourse by embracing such commitments and concerns.

Nonetheless, Mitroff (2003) goes further by suggesting that organizations will have to deal with new roles, job descriptions, and governing structures in order to express, maintain, and develop their spirituality. Admittedly, this process requires that ample strategic issues (especially moral and ethical ones) be formulated and, if well-done, it will forcefully culminate in pinpointing several organizations' shadows. Taken as a whole, this process could allow that a quality organization springs up and it would be a very promising upshot. In essence, it appears that the world is in great need of that kind of firms (see LOZANO and RIBEIRA, 2004, p. 179, for a review of its features).

In addition, researchers argue that employees want to work for organizations that are engaged in doing very well and a lot of good (SIROTA, MISCHKIND and MELTZER, 2005, p. 141). And this accomplishment can be seen through a set of policies, practices, and programs intertwined with business objectives and an underlying system of values focused on building long-term and positive relationships between the corporations and their stakeholders. Other relevant aspect raised by Biberman (2009) is that organizations may envision opportunities to start their spiritual journey exactly the same as individuals do. Given that an individual spiritual transformation may be triggered by critical events or as simple wishes to promote a selfexamination and reflection, an organization may deal with its own transformation as a, for example, consequence of change in leadership, company takeover or some sort of crisis likewise.

\section{Leadership Factor}

Admittedly, the implementation of a spiritual organization frame would require a special sort of leadership that is not found everywhere. Rather, I surmise that if work settings give enough room to the spiritual leaderships could exhibit their skills and virtues, we would have only outstanding companies to work for. However, Moxley (2000) notes that very few executives have consciously searched for their inner life in order to bring the internal forces of ego, power, and shadow into the light. In fact, it appears that spirituality 
is not seen as a priority or goal to be immediately reached by the majority of people. By the same token, I argue that the managers that are exclusively concerned with their own needs and well-being are not suited to put into practice the changes toward the adoption of the spiritual paradigm within their companies. Similarly, Frost (2003) argued that the majority of organizations and their leaders still continue to disrespect the feelings (especially the negative ones) which are yielded by their own policies and attitudes on employees. Nonetheless, I believe that the role of leadership is crucial for the concept of SBOs come true. Thus, I am aligned with Cacciope (2000a) when he stated that "We are at a time of history when we need to revise our entire view of ourselves, the nature of work and leadership of organizations" (p. 48). Within this perspective, management education and human resources field may strongly contribute to spiritually driven talents emerge and find at least some reasonable conditions to flourish.

Spiritual leadership cannot be regarded as a mature concept or well established theory (indeed, the same reasoning is worthy to SBOs). Researchers admit that spiritual leadership is a relatively new topic of investigation, as well as workplace spirituality (e.g., DENT, HIGGINS and WHARFF, 2005; FRY, 2005; KOLODINSKY, GIACALONE and JURKIEWICZ, 2008). However, what does characterize a spiritual leadership? Fry, Vitucci and Cedillo (2005) defines spiritual leadership as "the values, attitudes, and behaviors that one must adopt in intrinsically motivating one's self and others so that both have a sense of spiritual survival through calling and membership - i.e., they experience meaning in their lives, have a sense of making a difference, and feel understood and appreciated" (p. 836). More recently, Fry (2008, p. 108) refined somewhat that definition and added that the purpose of spiritual leadership is to meet the fundamental for the spiritual well-being of both leader and follower through calling and membership mechanisms in order to create vision and value congruence across the individual, empowered team, organizational commitment and productivity.

Viewed in this way, spiritual leadership embraces very sensitive topics (i.e., motivation, calling, and membership), which are, at first sight, not being appropriately addressed in organizations. After all, evidence shows that people are capable of doing extraordinary achievements as long as they are urged toward it. Therefore, it appears that the task of shaping SBOs may be regarded, on the face of the arguments examined throughout this paper, as a very motivating goal and worthy of taking part in it. Furthermore, researchers predict that successful organizational leaders of the twenty first century will be motivated by the spirit phenomenon or paradigm (e.g., CACCIOPE, 2000a). To some extent, Crossman's (2010) insights concur with that prediction. More specifically, she regards that the holistic and creative solutions to new organizational and world problems may be engendered through the conceptualization of spiritual leadership.

In addition, it is worth mentioning that senior managers play a very important role in order to trigger a spiritual leadership process (CACCIOPE, 2000b), given that they know, by and large, what must be done. In this regard, Guillory (2001) argues that spiritual leaders have an "innate sense of doing what is right, irrespective of the consequences" (p. 187). Put another way, the notion of spiritual leadership do not comply with wrongdoings, unfair decisions or ethical failures. In a broader view, Howard (2002) proposes that "The ultimate aim of a spiritual leader is to find the resources of character to meet his or her destiny - to find the wisdom and power to serve others" (p. 236). At this juncture, one can claim that the moral issue is a salient feature of the spiritual leadership construct. Korac-Kakabdase, Kouzmin and Kakabdase (2002, p. 173) go further by suggesting that spiritual leaders work to clarify their follower's moral identity, strengthen, and deepen their commitment. More specifically, it appears that they are able to trigger other's interior workloads of moral reflection, outer world of work, and social relationships. In a related vein, it is argued that one is welcoming spiritual topic because "despite the seemingly unproductive nature of spiritual activities as they take place, management trusts that workers will get their work done satisfactorily" (KOLODINSKY, BOWEN and FERRIS, 2003, p. 175-176).

In essence, spiritual leaders have been described as more "Homo moralis" rather than "Homo economicus". This reasoning rests on the argument that they pursue universal principles rather than being simply intelligent money-generating robots (HÉJJ, 2004). Moreover, spiritual leadership is associated with "the ideals of being self-aware and other-aware, but also "world-aware" (HOWARD and WELBOURN, 2004, p. 123). In sum, Fry, Hannah, Noel et al. (2011) believe that spiritual leadership can be identified through enabling altruistic 
love between group members toward pursuing a common vision. Taken together, one may deduce that spiritual leadership is vital to organizations embrace nobler goals and mission business and become SBOs. Thus, I propose that

Proposition 8: Spiritual leaderships likely play a vital role to organizations that pursue nobler goals (for example, as those exhibited at the right side of the Figure 1) and mission business in order to become SBOs.

\section{Some Counterpoints, Difficulties, and Problems}

Despite the optimistic perspectives presented so far, there remain some issues that need to be addressed, especially involving the practice, theoretical development, and lack of clarity related to the spirituality in organizations. For example, some researchers (e.g., GEN and TAN, 2009; PAUCHANT, 2002; TROTT, 1996) point out the tension that exists between traditional organizational goals (i.e., profit margins, job security, market share, and the pursuit of power) and the promotion of workplace spirituality. Furthermore, as posited by Eisler and Montuori (2003), "The challenge of transforming the workplace is in key respects a spiritual challenge. If we put partnership spirituality into action, business success and the highest human aspirations can meet" (p. 55). In this sense, Howard (2002, p. 232) ponders about the difficulties faced by managers in dealing with the concept of a "higher power" or "divine principle", given that they usually handle with the self, others, and environment issues. Additionally, Howard (2002) remarks: "We are still at the early stages of exploring just how organisations might become more spiritual, and what benefits or conflicts this might create" (p. 241, emphasis added). In a related vein, Gross-Schaefer (2009) regards that it would be difficult, perhaps even impossible, to fully convince everyone about the beneficial aspects derived from the introduction of values or spirituality in the organization.

Moreover, other obstacles deserve to be highlighted. Tourish and Tourish (2010), for instance, consider that workplace is not appropriate for people start their quest for finding deepest meaning in their lives. However, this argument is inaccurate regarding that people spend increasing time of their lives on working settings. Further, there is no sign that such frame will be reverted in the near future. In addition, there is no doubt that work is a potential source of human development, self-fulfillment, and happiness.

Nonetheless, it has been argued that the spirituality is a risk topic to be raised and discussed in the workplaces (LIPS-WIERSMA and MILLS, 2002). In a similar vein, Polley, Vora and SubbaNarasimha (2005) ask if organizations would gain by adopting spirituality in comparison with their competitors, given that they may have other perceptions. Obviously, this concern will require carefully analysis and longitudinal investigations. I surmise that an organization pursuing spirituality may likely lag behind vis-à-vis its rivals, at least in the first stage of shifting to this paradigm. But in a second stage, some advantages may be obtained in relation to aspects such as: corporate reputation, branding, corporate social responsibility, organizational citizenship and employees' engagement, commitment, and affect. Anyway, it has been also proposed that for spirituality in organizations "become a force for social change, it needs to question the neoliberal values and assumptions, particularly the exclusive focus on self-interest, and pay attention to that which assists projects of emancipation and sustainability such as distributive justice and social activism" (LIPS-WIERSMA and NILAKANT, 2008, p. 59).

However, Polley, Vora and SubbaNarasimha (2005) argue that spirituality in the workplace presents some limits, despite the benefits associated with human and organizational instances. In their view, spirituality in the workplace is subject to dilemmas, costs, and negative effects. Thus, in order to be successful six issues should be taken into account: 1) net economic cost of implementation; (2) potential for worker exploitation; (3) replacing or substituting community's function or role in spirituality; (4) inappropriate practice of spirituality in the workplace; (5) potential for competitive disadvantage and (6) increased groupthink. These authors also suggest that by adopting a spirituality frame organizations likely will generate some discomfort for their members in confronting their own held values that may not be aligned with universal ones. 
In a similar vein, Porth, Steingard and McCall (2003) emphasize the challenge of the spirituality frame may be noted throughout the organization, particularly in job design, culture, management style, reward system, vision, and mission, as well as to avoid the temptation to the old style of management. Biberman (2009) also addresses similar concerns. On the other hand, Driscoll and Wiebe (2007) state that there are clear examples of authentic spirituality in organizations, yet they admit to be still skeptical about its potentialities. Similarly, Lozano and Ribera (2004) note: "One of Man's greatest challenges would then be how to work on spirituality, how to develop it, how to bring it to its maximum splendor. This would involve an additional challenge: the search for ways to make spirituality explicit not only individually but also the organizational context, within structured human groups" (p. 176). Therefore, one may infer that organizations would have to work hard to incorporate spirituality de facto as a business philosophy. After all, it will require that they adopt and implement ongoing and very articulated efforts and measures.

Moreover, there is a justifiable concern that organizations may attempt to manipulate it as a tool aiming at increasing productivity and profitability (e.g., MILLIMAN, CZAPLEWSKI and FERGUSON, 2003). In this regard, Lips-Wiersma, Dean and Fornaciari (2009) posit an interesting matrix that addresses two potentially negative dimensions of organizational experience: control and instrumentality. This is conceptualized through four quadrants (i.e., seduction, evangelization, manipulation, and subjugation) that could undermine initiatives toward workplace spirituality. Further, it suggests that those organizations that fit into such a conceptual model do not regard spirituality as a purpose. Thus, "Legitimizing workplace spirituality therefore requires a demonstrable positive impact of spiritual variables on workplace-related functioning. Without this demonstration, the topic of workplace spirituality would be marginalized as a philosophical and impractical pursuit" (GIACALONE, JURKIEWICZ and FRY, 2005, p. 517). In addition, it is predicted that there could have some skepticism emanated from some members of the organization who might never support such efforts and even looking for ways of sabotaging them (GROSS-SCHAEFER, 2009).

With reference to the theoretical problems, many authors argue about the need of a more precise definition about the concept of SBO (e.g., GEN and TAN, 2009; GIBBONS, 2000; KLERK, 2005; KOLODINSKY, GIACALONE and JURKIEWICZ, 2008). In fact, there is no consensus about what the concept of SBO really means. As previously noted, however, being spirituality a multi-dimensional or multi-faceted concept, it would be naïve, then, to expect that it is an easy task. As rightly put by Ingersoll (2003), "Addressing spirituality, let alone spirituality in the workplace, is a daunting task" (p. 297). Within this perspective, more scholars should consider the challenge of working on this fascinating endeavor by outlining a complex construct, as well as by attempting to identify its theoretical features and ramifications.

In this sense, Gozdz (2000) calls attention to the fact that we are strongly influenced by the Western orthodox science worldview. As a consequence, it has been prevailed the foundations of logical positivism, empiricism, reductionism, rationalism, objectivity, Newtonian-Cartesian mechanical lawful universe, and the quantification of reality. In fact, Daniels, Franz and Wong (2000) argue that references to spirituality tend to be seen as something unintelligible or even naive and, as such, it is "dismissed in favor of one's centered on the 'hard' or quantifiable business disciplines" (p. 546). Following the same line of reasoning, Gotsis and Kortezi (2008) point out that the eventual qualitative positive outcomes of spiritually oriented workplace (e.g., enhanced morale and communication) could be associated with the materialistic goal of improving organizational efficiency, which would raise concerns. Furthermore,

The reductionist bent of the positivist model paradigm resists incorporating crucial elements of spirituality and religion in organizations research because concepts such as soul, spirit, faith, and morality are not measurable in conventional ways and are by definition non-reductionist. These concepts cannot be observed and recorded like physical traits or acts, do not themselves to short, neat questions appropriate for a Likert scale, and defy consensus as to their very meaning, making quantitative research operationalization nearly impossible. (FORNACIARI and DEAN, 2001, p. 337) 
On the other hand, Brown (2003) surmises that some concepts attributed to spiritual realm can be a repacking or branding of certain concepts perhaps derived from Organizational Development (OD). Likewise, one may raise the same perception from virtuousness in organizations (CAMERON, CAZA and BRIGHT, 2008; CAMERON and WINN, 2012). With reference to these points, it is notorious that the concept of SBO presents, to some degree, convergences, commonalities, and overlaps with both OD and virtuousness theory; nonetheless, it appears to have more theoretical ambitions.

\section{Future studies and Conclusion}

First and foremost, I recognize that SBO literature is extremely descriptive and conceptual in nature, requiring further reliable evidence-based data in order to support its assumptions. Accordingly, such an aspect can be considered, therefore, the major limitation of my endeavor. Nonetheless, this literature review also found evidence that substantial benefits and praiseworthy characteristics have been associated with the concept of SBOs. Rather, they appear to be excellent companies to work for because they strive to provide meaningful experiences, feelings of membership and calling, and humanistic policies to their employees. In addition, SBOs are seen as committed to working well and, most importantly, doing good. Therefore, future investigations should continue to identify firms that fit into SBOs theoretical framework. Again, I suggest that one can identify their organizational identity (i.e., who they really are) by investigating their achievements, organizational policies, strategies, held values, official statements, among other aspects. Importantly, the concept of SBO is somewhat elusive requiring conceptual frameworks developments and fundamentally more testable empirical models. In addition, specific scales could be developed in order to measure the effects and impacts of SBO. In fact, the paucity of empirical investigation related to SBOs represents a gap in the development of this theory that needs to be appropriately fulfilled. Thus, will spirituality be merely employed as an organizational discourse in order to enhance profit or as a moral foundation to guide business enterprises? These are pertinent questions that deserve to be investigated.

In sum, research has indicated that the material paradigm is not suited to deal with germane problems that shape today's world. Business models that stimulate individuals' selfish, indifference, and negative feelings have been strongly criticized. Moreover, organizations that tend to be uncaring toward environment and society, as well as poor values-driven are increasingly stigmatized. Thus, the ubiquitous failures, disruptions, inequalities, and other anomalies yielded by this sort of organizational system have signaled that the spiritual paradigm demands careful attention from both people and organizations. In this regard, the evidence gathered throughout this paper suggests that the spiritual paradigm starts to play a key role alongside with the concept SBOs, despite the counterpoints that were discussed. For this reason, I believe that these topics can be regarded as authentic imperatives for this millennium. Nonetheless, it is likely to take some time until spirituality topic may mold, so to speak, organizations' character regarding that spiritual theme is starting to become a noteworthy topic. At present, however, it is seen as a belief (BROWN, 2003).

On the face of it, education and human resource development (GIOIA, 2003; KETOLA, 2006; KUCHINKE, 2010) are crucial in terms of providing an organizational environment where spiritually driven talents (potential spiritual leaderships) can show their faces without fear and find opportunities to express their full capabilities and virtuous. I consider that this kind of leaders is vital to change organizations toward spiritual paradigm given that they usually exhibit features and concerns that may enable that SBOs take shape. 


\section{References}

ALTAF, A.; AWAN, M. A. Moderating affect of workplace spirituality on the relationship of job overload and job satisfaction. Journal of Business Ethics, v. 104, n. 1, p. 93-99, 2011.

ASHAR, H.; LANE-MAHER, M. Success and spirituality in the new business paradigm. Journal of Management Inquiry, v. 13, n. 3, p. 249-60, 2004.

ASHFORTH, B. E.; PRATT M. G. Institutionalized spirituality: an oxymoron? In: GIACALONE, R. A.; JURKIEWICZ, C. L. (Eds.). Handbook of Workplace Spirituality and Organizational Performance. Armonk: M. E. Sharpe, 2003. 93-107 p.

BADRINARAYANAN, V.; MADHAVARAM, S. Workplace spirituality and the selling organization: a conceptual framework and research propositions", Journal of Personal Selling \& Sales Management, v. 28, n. 4, p. 421-434, 2008.

BAKKE, D. W. Joy at work: a revolutionary approach to fun on the job. Seattle: PVG, 2005.

BALCH, D. R.; ARMSTRONG, R. W. Ethical marginality: the Icarus syndrome and banality of wrongdoing. Journal of Business Ethics, v. 92, n. 2, p. 291-303, 2010.

BENEFIEL, M. Soul at work: spiritual leadership in organizations. New York: Seabury Books, 2005.

BIBERMAN, J. What makes an organization spiritual? Applied spirituality in organizational structure, design, processes, and practices. In: MARQUES, J.; DHIMAN, S.; KING, R. (Eds.). The Workplace and Spirituality: New Perspectives on Research and Practice. Woodstock: Skylight Paths Publishing, 2009. 111-118 p.

BIBERMAN, J.; WHITTY, M. A. A postmodern spiritual future for work. Journal of Organizational Change Management, v. 10, n. 2, p. 130-138, 1997.

BODDY, C. R. The corporate psychopaths theory of the global financial crisis. Journal of Business Ethics, v. 102 , n. 2, p. 255-259, 2011.

BROWN, R. B. Organizational spirituality: the sceptic's version. Organization, v. 10, n. 2, p. 393-400, 2003.

CACIOPPE, R. Creating spirit at work: re-visioning organization development and leadership - Part I. Leadership \& Organization Development Journal, v. 21, n. 1/2, p. 48-54, 2000a.

CACIOPPE, R. Creating spirit at work: re-visioning organization development and leadership - Part II. Leadership \& Organization Development Journal, v. 21, n. 1/2, p. 110-119, 2000 b.

CALDWELL, C.; CANUTO-CARRANCO, M. 'Organizational terrorism' and moral choices - exercising voice when the leader is the problem. Journal of Business Ethics, v. 97, n. 1, p. 159-171, 2010.

CAMERON, K.; CAZA, A.; BRIGHT, D. Positive deviance, organizational virtuousness, and performance. Working paper, University of Michigan - Ross School of Business, 2008.

CAMERON, K.; DUTTON, J. E.; QUINN, R. E. Foundations of positive organizational scholarship. In: CAMERON, K. S.; DUTTON, J. E.; QUINN, R. E. (Eds.). Positive Organizational Scholarship: Foundations of a New Discipline. San Francisco: Berret-Koelher, 2003. p. 3-13.

CAMERON, K.; WINN, B. Virtuousness in organizations. In: CAMERON, K. S.; SPREITZER, G. M. (Eds.). The Oxford Handbook of Positive Organizational Scholarship. New York: Oxford University Press, 2012. 231-243 p.

CAVANAGH, G. et al. Toward a spirituality for the contemporary organization: implications for work, family, and society. In: PAVA, M. L.; PRIMEAUX, P. (Eds.). Spiritual Intelligence at Work: Meaning, Metaphor, and Morals. Research in Ethical Issues in Organizations. v. 5. Oxford: Elsevier Ltd., 2004. 111-138 p. 
CHAMIEC-CASE, R. R. Developing a tool measure social worker's perceptions regarding to extent to which they integrate their spirituality in the workplace. Doctoral dissertation, Graduate School of Social Science, Fordham University, 2006.

CROPANZANO, R.; BOWEN, D. E.; GILLILAND, S. W. The management of organizational justice. Academy of Management Perspectives, v. 21, n. 4, p. 34-48, 2007.

CROSSMAN, J. Conceptualising spiritual leadership in secular organizational contexts and its relation to transformational, servant and environmental leadership. Leadership and Organization Development Journal, v. 31, n. 7, p. 596-608, 2010.

DANIELS, D.; FRANZ, R. S.; WONG, K. A classroom with a worldview: making spiritual assumptions explicit in management education. Journal of Management Education, v. 24, n. 5, p. 540-561, 2000.

DAVIS, G. F.; COBB, J. A. Corporations and economic inequality around the world: the paradox of hierarchy. Research in Organizational Behavior, v. 30, p. 35-53, 2010.

DELBECQ, A. L. Spirituality and business: one scholar's perspective. Journal of Management, Spirituality and Religion, v. 6, n. 1, p. 3-13, 2009.

DENT, E. B.; HIGGINS, M. E.; WHARFF, D. M. Spirituality and leadership: an empirical review of definitions, distinctions, and embedded assumptions. The Leadership Quarterly, v. 16, n. 5, p. 625-653, 2005.

DHIMAN, S.; MARQUES, J. The role and need of offering workshops and courses on workplace spirituality", Journal of Management Development, v. 30, n. 9, p. 816 - 835, 2011.

DRISCOLL, C.; WIEBE, E. Technical spirituality at work: Jacques Ellul on workplace spirituality. Journal of Management Inquiry, v. 16, n. 4, p. 333-348, 2007.

EISLER, R.; MONTUORI, A. The human side of spirituality. In: GIACALONE, R. A.; JURKIEWICZ, C. L. (Eds.). Handbook of Workplace Spirituality and Organizational Performance. Armonk: M. E. Sharpe, 2003. 46-56 p.

EMMONS, R. A. The psychology of ultimate concerns. New York: The Guilford Press, 1999.

EVERS, F. T.; REID, L. Addressing wellness problems in the workplace through spirituality: six risks and six spiritual solutions. In: MARQUES, J.; DHIMAN, S.; KING, R. (Eds.). The Workplace and Spirituality: New Perspectives on Research and Practice. Woodstock: Skylight Paths Publishing, 2009. 119-128 p.

EXLINE, J. J.; BRIGHT, D. S. Spiritual and religious struggles in the workplace. Journal of Management, Spirituality and Religion, v. 8, n. 2, p. 123-142, 2011

FALEYE, O; TRAHAN, E. A. Labor-friendly corporate practices: is what is good for employees good for shareholders? Journal of Business Ethics, v. 101, n. 1, p. 1-27, 2011.

FELIX, A.; SAlgADO, R.; BALIEIRO, S. A dura vida de CEO. Época Negócios, São Paulo, n. 74, abril, p. 66-73, 2013.

FORNACIARI, C. J.; DEAN, K. L. Making the quantum leap: lessons from physics on studying spirituality and religions in organizations. Journal of Organizational Change Management, v. 14, n. 4, p. 335-351, 2001.

FREITAS, M. E. Cultura organizacional: identidade, sedução e carisma? Rio de Janeiro: FGV Editora, 1999.

FROST, P. J. Emoções tóxicas no trabalho. São Paulo: Futura, 2003.

FRY, L. W. Toward a theory of ethical and spiritual well-being, and corporate social responsibility through spiritual leadership. In: GIACALONE, R. A.; JURKIEWICZ, C. L.; DUNN, C. (Eds.). Positive Psychology in Business Ethics and Corporate Responsibility. Greenwich: Information Age Publishing, 2005. 47-83 p. 
FRY, L. W. Spiritual leadership: state-of-the-art and future directions for theory, research, and practice. In: BIBERMAN, J.; TISCHLER, L. (Eds.). Spirituality in Business: Theory, Practice, and Future Directions. New York: Palgrave Macmillan, 2008. 106-124 p.

FRY, L. W.; VITUCCI, S.; CEDILLO, M. Spiritual leadership and army transformation: theory, measurement, and establishing a baseline. The Leadership Quarterly, v. 16, n. 5, p. 835-862, 2005.

FRY, L. W. et al. Impact of spiritual leadership on unit performance. The Leadership Quarterly, v. 22, n. 2, p. 259$270,2011$.

GARCIA-ZAMOR, J.-C. Workplace spirituality in the United States and former East Germany. In: GIACALONE, R. A.; JURKIEWICZ, C. L. (Eds.). Handbook of Workplace Spirituality and Organizational Performance. Armonk: M. E. Sharpe, 2003. 314-335 p.

GAVIN, J. H.; MASON, R. O. The virtuous organizations: the value of happiness in the workplace. Organizational Dynamics, v. 33, n. 4, p. 379-392, 2004.

GEH, E.; TAN, G. Spirituality at work in a changing world: managerial and research implications. Journal of Management, Spirituality, and Religion, v. 6, n. 4, p. 287-300, 2009.

GIACALONE, R. A.; JURKIEWICZ, C. L.; FRY, L. W. From advocacy to science: the next steps in workplace spirituality research. In: PALOUTZIAN, R. F.; PARK, C. L. (Eds.). Handbook of the Psychology of Religion and Spirituality. New York: The Guilford Press, 2005. 515-528 p.

GIBBONS, P. Spirituality at work: definitions, measures, assumptions, and validity claims. Proceedings of the Academy of Management, USA, 2000.

GIOIA, D. A. Business organization as instrument of societal responsibility. Organization, v. 10, n. 3, p. 435-438, 2003.

GLAVAS, A.; PIDERIT, S.K. How does doing good matter? Effects of corporate citizenship on employees. Journal of Corporate Citizenship, n. 36, p. 51-70, 2009.

GOTSIS, G.; KORTEZI, Z. Philosophical foundations of workplace spirituality: a critical approach. Journal of Business Ethics, v. 78, n. 4, p. 575-600, 2008.

GOZDZ, K. Toward transpersonal learning communities in business. The American Behavioral Scientist, v. 43, n. 8, p. 1262-1285, 2000.

GROSS-SCHAEFER, A. Reaching for the stars: effective tools for the creation of a more spiritual workplace. Employee Relations Law Journal, v. 35, n. 1, p. 25-42, 2009.

GRZEDA, M.; ASSOGBAVI, T. Spirituality in management education and development: toward an authentic transformation. Journal of American Academy of Business, v. 16, n. 2, p. 238-244, 2011.

GUILLORY, W. A. The living organization: spirituality in the workplace. 2. ed. Salt Lake City: Innovations International, 2001.

GULL, G. A.; DOH, J. The 'transmutation' of the organization: toward a more spiritual workplace. Journal of Management Inquiry, v. 13, n. 2, p. 128-139, 2004.

HAYAKAWA, E. Inspired leadership: leading with spirit. In: MARQUES, J.; DHIMAN, S.; KING, R. (Eds.). The Workplace and Spirituality: New Perspectives on Research and Practice. Woodstock: Skylight Paths Publishing, 2009. 67-74 p.

HÉJJ, T. The economy of sharing. In: ZSOLNAI, L. (Ed.). Spirituality and Ethics in Management. Dordrecht: Kluwer Academic Publishers, 2004. 141-151 p. 
HOWARD, S. A spiritual perspective on learning in the workplace. Journal of Managerial Psychology, v. 17, n. 3, p. 230-242, 2002.

HOWARD, S.; WELBOURN, D. The spirit at work phenomenon. London: Azure, 2004.

INGERSOLL, R. E. Spiritual wellness in the workplace. In: GIACALONE, R. A.; JURKIEWICZ, C. L. (Eds.). Handbook of Workplace Spirituality and Organizational Performance. Armonk: M. E. Sharpe, 2003. 289-299 p.

JOHNSON, C. E. Spirituality and ethical leadership: moral persons and moral managers. In: MARQUES, J.; DHIMAN, S.; KING, R. (Eds.). The Workplace and Spirituality: New Perspectives on Research and Practice. Woodstock: Skylight Paths Publishing, 2009. 75-86 p.

KARAKAS, F. Spirituality and performance in organizations: a literature review. Journal of Business Ethics, v. 94, n. 1, p. 89-106, 2010.

KARDEC, A. The spirits' book. (Translated from the Le Livre des Esprits, 1857). Philadelphia: Allan Kardec Educational Society, 2003.

KETOLA, T. From CR-psychopaths to responsible corporations: waking up the inner sleeping beauty of companies. Corporate Social Responsibility and Environmental Management, v. 13, n. 2, p. 98-107, 2006.

KHISTY, C. J. The practice of mindfulness for managers in the marketplace. Systemic Practice and Action Research, v. 23, n. 2, p. 115-125, 2010.

KINJERSKI, V.; SKRYPNEK, B. J. Defining spirit at work: Finding common ground. Journal of Organizational Change Management, v. 17, n. 1, p. 26-42, 2004.

KLERK, J. J. de. Spirituality, meaning in life, and work wellness: a research agenda. International Journal of Organizational Analysis, v. 13, n. 1, p. 64-88, 2005.

KOLODINSKY, R. W.; BOWEN, M. G.; FERRIS, G. R. Embracing workplace spirituality and managing organizational politics: servant leadership and political skill for volatile times. In: GIACALONE, R. A.; JURKIEWICZ, C. L. (Eds.). Handbook of Workplace Spirituality and Organizational Performance. Armonk: M. E. Sharpe, 2003. $164-180 \mathrm{p}$.

KOLODINSKY, R. W.; GIACALONE, R. A.; JURKIEWICZ, C. L. Workplace values and outcomes: exploring personal, organizational, and interactive workplace spirituality. Journal of Business Ethics, v. 81, n. 2, p. 465-480, 2008 .

KORAC-KAKABDASE, N.; KOUZMIN, A.; KAKABDASE, A. Spirituality and leadership praxis. Journal of Managerial Psychology, v. 17, n. 3, p. 165-182, 2002.

KUCHINKE, K. P. Human development as a central goal for human resource development. Human Resource Development International, v. 13, n. 5, p. 575-585, 2010.

LAVINE, M. et al. Exploring the generative potential between positive organizational scholarship and management, spirituality, and religion research. Journal of Management, Spirituality and Religion, v. 11, n. 1, p. 6-26, 2014.

LAWLER, E. E., III. Treat people right: how organizations and individuals can propel each other into a virtuous spiral of success. San Francisco: Jossey-Bass, 2003.

LEAVITT, H. J. Big organizations are unhealthy environments for human beings. Academy of Management Learning and Education, v. 62, n. 2, p. 253-263, 2007.

LIMA, G. S.; CARVALHO NETO, A.; TANURE, B. Executivos jovens e seniores no topo da carreira: Conflitos e complementaridades. REAd - Revista Eletrônica de Administração, v. 18, n. 1, p. 63-96, 2012. 
LIPS-WIERSMA, M.; DEAN, K. L.; FORNACIARI, C. J. Identifying and managing the shadow of workplace spirituality: practical guidelines. In: MARQUES, J.; DHIMAN, S.; KING, R. (Eds.). The Workplace and Spirituality: New Perspectives on Research and Practice. Woodstock: Skylight Paths Publishing, 2009. 177-187 p.

LIPS-WIERSMA, M.; MILLS, C. Coming out of the closet: negotiating spiritual expression in the workplace. Journal of Managerial Psychology, v. 17, n 3, p. 183-202, 2002.

LIPS-WIERSMA, M.; NIKALANT, V. Practical compassion: toward a critical spiritual foundation for corporate responsibility. In: BIBERMAN, J.; TISCHLER, L. (Eds.). Spirituality in Business: Theory, Practice, and Future Directions. New York: Palgrave Macmillan, 2008. 51-72 p.

LÓPEZ, L. H.; RAMOS, R. R.; RAMOS, S. R. Spiritual behaviour in the workplace as a topic for research. Journal of Management, Spirituality and Religion, v. 6, n. 4, p. 273-285, 2009.

LOZANO, J. M.; RIBERA, R. A new chance for management - a new challenge for spirituality. In: ZSOLNAI, L. (Ed.). Spirituality and Ethics in Management. Dordrecht: Kluwer Academic Publishers, 2004. 175-185 p.

LUTHANS, F. The need for and meaning of positive organizational behavior. Journal of Organizational Behavior, v. 23, n. 6, p. 695-706, 2002.

LUTHANS, F. et al. Positive psychological capital: measurement and relationship with performance and satisfaction. Personnel Psychology, v. 60, n. 3, p. 541-572, 2007.

MARCIC, D. God, faith, and management education. Journal of Management Education, v. 24, n. 5, p. 628-649, 2000 .

MARQUES, J.; DHIMAN, S.; KING, R. Spirituality in the workplace: what it is, why it matters, how to make it works for you. Fawnskin: Personhood Press, 2007.

MARQUES, J. F. Spiritual performance from an organizational perspective: the Starbucks way. Corporate Governance, v. 8, n. 3, p. 248-257, 2007.

MCGEE, J. J.; DELBECQ, A. L. Vocation as a critical factor in a spirituality for executive leadership in business. In: WILliAMS, O. F. (Ed.). Business, Religion, and Spirituality: A New Synthesis. Notre Dame: University of Notre Dame Press, 2003. 94-110 p.

MCKNIGHT, R. Spirituality in the workplace. In: ADAMS, J. D. (Ed.). Transforming Work. 2. ed. New York: Cosimo on Demand, 2005. 160-177 p.

MEIRA, F. B. A ética empresarial em movimento: as (de)limitações do campo. Gestão \& Planejamento, v. 11, n. 1, p. $119-138,2010$.

MILLIMAN, J.; CZAPLEWSKI, A. J.; FERGUSON, J. Workplace spirituality and employee work attitudes: an exploratory empirical assessment. Journal of Organizational Change Management, v. 16, n. 4, p. 426-447, 2003.

MILLIMAN, J. et al. Spirit and community at Southwest airlines: an investigation of a spiritual values-based model. Journal of Organizational Change Management, v. 12, n. 3, p. 221-233, 1999.

MITROFF, I. I. On the fundamental importance of ethical management: why management is the most important of all human activities. Journal of Management Inquiry, v. 7, n. 1, p. 68-79, 1998.

MITROFF, I. I. Business not as usual: reflections on spirituality in the workplace. In: WILLIAMS, O. F. (Ed.). Business, Religion, and Spirituality: A New Synthesis. Notre Dame: University of Notre Dame Press, 2003. 187-200 p.

MITROFF, I. I.; DENTON, E. A. A spiritual audit of corporate America: a hard look at spirituality, religion, and values in the workplace. San Francisco: Jossey-Bass, 1999. 
MOXLEY, R. S. Leadership and spirit: breathing new vitality and energy into individuals and organizations. San Francisco: Jossey-Bass, 2000.

NECK, C. P.; MILLIMAN, J. F. Thought self-leadership: finding spiritual fulfillment in organizational life. Journal of Managerial Psychology, v. 9, n. 6, p. 9-16, 1994.

NOBLE, K. D. Riding the windhorse: spiritual intelligence and the growth of the self. Cresskill: Hampton Press, 2001.

OUIMET, J.-R. Reconciling human happiness and profitability: mission possible thanks to sixteen new management tools. In: PAUCHANT, T. C. (Ed.). Ethics and Spirituality at Work: Hopes and Pitfalls of the Search for Meaning in Organizations. Westport: Quorum Books, 2002. 77-88 p.

PANDEY, A.; GUPTA, R. K. A perspective of collective consciousness of business organizations. Journal of Business Ethics, v. 80, n. 4, p. 889-898, 2008.

PARGAMENT, K. I.; MAHONEY, A. Spirituality: discovering and conserving the sacred. In: SNYDER, C. R.; LOPEZ, S. J. (Eds.). Handbook of Positive Psychology. New York: Oxford University Press, 2005. 646-659 p.

PARK, N.; PETERSON, C. M. Virtues and organizations. In: CAMERON, K. S.; DUTTON, J. E.; QUINN, R. E. (Eds.). Positive Organizational Scholarship: Foundations of a New Discipline. San Francisco: Berret-Koelher, 2003. 33-47 p.

PAUCHANT, T. C. Introduction: Ethical and spiritual management addresses the need for meaning in the workplace. In: PAUCHANT, T. C. (Ed.). Ethics and Spirituality at Work: Hopes and Pitfalls of the Search for Meaning in Organizations. Westport: Quorum Books, 2002. 1-28 p.

PAVA, M. L. Searching for spirituality in all the wrong places. Journal of Business Ethics, v. 48, n. 4, p. 393-400, 2003.

PAVLOVICH, K.; CORNER, P. D. Spiritual organizations and connectedness: the Living Nature experience. Journal of Management, Spirituality and Religion, v. 6, n. 3, p. 209-229, 2009.

PFEFFER, J. Business and the spirit: management practices that sustain values. In: GIACALONE, R. A.; JURKIEWICZ, C. L. (Eds.). Handbook of Workplace Spirituality and Organizational Performance. Armonk: M. E. Sharpe, 2003. 29-45 p.

POLLEY, D.; VORA, J.; SUBBANARASIMHA, P. N. Paying the devil his due: limits and liabilities of workplace spirituality. International Journal of Organizational Analysis, v. 13, n. 1, p. 50-63, 2005.

PORTH, S. J.; STEINGARD, D.; MCCALL, J. Spirituality and business: the latest management fad or the next breakthrough. In: WILliAMS, O. F. (Ed.). Business, Religion, and Spirituality: A New Synthesis. Notre Dame: University of Notre Dame Press, 2003. 249-262 p.

QUATRO, S. A. Organizational spiritual normativity as an influence on organizational culture and performance in Fortune 500 firms. Doctoral dissertation, Iowa State University, 2002.

RENESCH, J. Humanizing capitalism: vision of hope; challenge for transcendence. Journal of Human Values, v. 14, n. 1, p. 1-9, 2008.

SELIGMAN, M. E. P.; CSIKSZENTMIHALYI, M. Positive psychology: an introduction. American Psychologist, v. 55 , n. 1, p. 5-14, 2000.

SIROTA, D.; MISCHKIND, L. A.; MELTZER, M. I. The enthusiastic employee: how companies profit by giving workers what they want. Saddle River: Wharton School Publishing Upper, 2005.

STEAD, J. G.; STEAD, W. E. Building spiritual capabilities to sustain sustainability-based competitive advantages. Journal of Management, Spirituality \& Religion, v. 11, n. 2, p. 143-158, 2014. 
STEINGARD, D. S. Spiritually-informed management theory: toward profound possibilities for inquiry and transformation. Journal of Management Inquiry, v. 14, n. 3, p. 227-241, 2005.

STOLTZ-LOIKE, M. Creating personal and spiritual balance: another dimension in career development. In: BLOCH, D. P.; RICHMOND, L. J. (Eds.). Connections Between Spirit and Work in Career Development: New Approaches and Practical Perspectives. Palo Alto: Davies-Black Publishing, 1997. 139-161 p.

SUTCLIFFE, K. M.; CHRISTIANSON, M. K. Managing the unexpected. In: SPREITZER, G.; CAMERON, K. S. (Eds.). Handbook of Positive Organizational Scholarship. Oxford: Oxford University Press, 2012. 843-854 p.

TACEY, D. The spirituality revolution: the emergence of contemporary spirituality. New York: Brunner-Routledge, 2004.

THOMPSON, W. D. Can you train people to be spiritual? Training and Development, v. 54, n. 12, p. 18-19, 2000.

TOURISH, D.; TOURISH, N. Spirituality at work, and its implications for leadership and followership: a poststructuralist perspective. Leadership, v. 6, n. 2, p. 207-224, 2010.

TROTT, D. C. Spiritual well-being of workers: an exploratory study of spirituality in the workplace. Doctoral dissertation, Graduate School of The University of Texas at Austin, 1996.

TWIGG, N. W.; PARAYITAM, S. Spirit at work: spiritual typologies as theory builders. Journal of Organization Culture, Communication and Conflict, v. 10, n. 2, p. 117-133, 2006.

VASCONCELOS, A. F. Espiritualidade no ambiente de trabalho: dimensões, reflexões e desafios. São Paulo: Editora Atlas, 2008.

VASCONCELOS, A. F. Spiritual development in organizations: a religious-based approach. Journal of Business Ethics, v. 93, n. 4, p. 607-622, 2010.

VASCONCELOS, A. F. Societal marketing concept and spirituality in the workplace theory: finding the common ground. Cadernos EBAPE.BR, v. 9, n. 1, p. 97-116, 2011 a.

VASCONCELOS, A. F. Pursuing organizational spirituality: some lessons from a financial services corporation. Management \& Marketing, v. 6, n. 3, p. 365-392, 2011 b.

VASCONCELOS, A. F. Examining workers' perception of spirituality in the workplace: an exploratory study. Management \& Marketing, v. 8, n. 2, p. 231-260, 2013.

WADDOCK, S. Positive psychology of leading corporate citizenship. In: GIACALONE, R. A.; JURKIEWICZ, C. L.; DUNN, C. (Eds.). Positive Psychology in Business Ethics and Corporate Responsibility. Greenwich: Information Age Publishing, 2005. 23-45 p.

WADDOCK, S.; MCINTOSH, M. Beyond corporate responsibility: implications for management development. Business and Society Review, v. 114, n. 3, p. 295-325, 2009.

WAGNER-MARSH, F.; CONLEY, J. The fourth wave: the spiritually-based firm. Journal of Organizational Change Management, v. 12, n. 4, p. 292-302, 1999.

ZAIDMAN, N.; GOLDSTEIN-GIDONI, O. Spirituality as a discarded form of organizational wisdom: field-based analysis. Group \& Organization Management, v. 36, n. 5, p. 630-653, 2011.

ZOHAR, D.; MARSHALL, I. Spiritual capital: wealth we can live by. San Francisco: Berret-Koehler Publishers, 2004. 